Aynur Bagir ${ }^{1}$

Department of Child Development, Faculty of Health Sciences

Inonu University Malatya, Turkey

Asist. Prof. Dr. Oguz Emre

Department of Child Development, Faculty of Health Sciences

Inonu University Malatya, Turkey

Prof. Dr. Hatice Birgul Cumurcu ${ }^{3}$

Department of Psychiatry, Faculty of Medicine

Inonu University Malatya, Turkey

Assoc. Prof. Dr. Aysegul Ulutas ${ }^{4}$

Department of Child Development, Faculty of Health Sciences

Inonu University Malatya, Turkey
Original scientific paper

UDC: 37.015 .4

DOI: $10.5937 /$ istrped2001050B

\title{
THE RELATIONSHIP BETWEEN SOCIAL EXCLUSION (OSTRACISM) AND INTERNET ADDICTION OF ADOLESCENT GIRLS
}

\begin{abstract}
This study aims to investigate the relationship between Internet addiction and social exclusion in female adolescents. The relational screening method was used in the study. The sample group of the study consisted of 244 female adolescents aged 12-18 living in Cinar district of Diyarbakir. To determine the exclusion of adolescents in social relations, the Social Exclusion Scale for adolescents has been used as a data collection tool. Besides, Young Internet addiction Short Form developed by Young (1998) which is the short form created by Pawlikowski, Altstotter-Gleich \& Brand (2013) and adapted to Turkish by Kutlu, Savci, Demir and Aysan (2016) has been used to test adolescents' internet addiction. Independent groups t-test, Mann-Whitney $\mathrm{U}$ test, Kruskal-Wallis test, Dunn-Bonferroni test, and Spearman correlation analysis were used for data analysis. According to the results of the study, it was found that there was no statistically significant relationship between exclusion score averages and an average of Internet addiction scores ( $p$ > 0.05).
\end{abstract}

Keywords: Internet Addiction, Social Exclusion (Ostracism), Adolescent Girls.

\section{Introduction}

The Internet, which was created to provide information, and communication, has become a structure that is widely used for entertainment and pleasure while providing chat, message, social media, and news. One of the most important reasons for the increase in the usage rate of the Internet with a great effect on facilitating human life along with its advantages is that it

\footnotetext{
1 aynurbag@gmail.com

2oguz.emre@inonu.edu.tr

${ }^{3}$ hatice.cumurcu@inonu.edu.tr

4 aysegul.ulutas@inonu.edu.tr
} 
can be accessible inexpensively and fast. Due to the numerous features of the Internet, the time spent on the Internet is increasing. As a result of this increase, the person who spends a lot of time on the Internet can have problems such as muscle and skeletal system disorders and physical problems such as head, neck, eye pain, as well as mental problems such as anxiety, addiction, sadness, depression, and thoughtlessness (Kayri \& Gunuc; 2009).

With the development of technology, the problems of today have begun to show diversity. Addiction is one of these issues. The idea of addiction, which has different definitions, is derived from the Latin word "addicere," meaning dedicating oneself to someone else (Minaz and Cetinkaya, 2017). Addiction can be defined as "the continued use of a substance or activity that harms the mental and physical health or social life of individuals, even if it affects them in a bad way, and the inevitable desire to repeat the intake or action of that substance" (Unal, 2015). Addiction which is commonly referred to as drug and alcohol addiction can be discussed in two classes and may be associated with different behaviours. Substance abuse includes cigarettes, alcohol, caffeine, marijuana, and cocaine as the drugs in the body, while physical dependence includes exercise, branding, obesity, gambling, the Internet, social media, smartphones and television addictions. Behavioral addiction includes exercise, brand, obesity, gambling, internet, social media, smartphone, and television addiction. Behavioral addiction is defined as the loss of function, disruption of balance and failure to adapt to society in terms of physical, social, psychological and social structure as a result of some behaviours with abnormal degrees and intensity (Canogullar, 2014).

The Internet causes addiction as much as it arouses excitement in the individual. In the family, work and social life among the people suffering from continuous internet use are defined as Internet addiction (Gwinnell \& Adamec, 2006; Dogan, 2013). Internet addiction was first investigated in the 1995s (Yellowlees \& Marks, 2007). Evidence has shown that abuse of the Internet has induced addiction to the Internet as well as gambling, sex and shopping (Bolukbas, 2003). The movement towards technical technology has increased as it provides a good source of information and promotes learning. Education is, therefore, given about the use of technological tools in schools. The fact that students are concerned with such technological devices has both positive and negative aspects. In the studies conducted with different societies in mind, it was found that adolescents took first place in Internet addiction risk groups. Adolescents often connect to the Internet in environments such as school, home and Internet cafes and they are preparing the ground for Internet addiction (Kayri \& Gunuc; 2009).

According to the survey entitled "Household Information Technology Use Research" conducted by TURKSTAT in 2017, the use of computers and the Internet in the 16-74 age group is $56.6 \%$ and $66.8 \%$, respectively. The rate of computer use was $65.7 \%$ in males and $47.7 \%$ in females in the $16-74$ age group. Internet usage rates were $58.7 \%$ for women and $75 \%$ for men. In Turkey, as part of the same research, it has found that 8 out of every 10 households have Internet access opportunities (TUIK, 2017).

Human is a social being and needs social relations to meet his needs. One of the most important factors that prevent a person from establishing and maintaining a positive relationship in society is to live in social exclusion (ostracism). Social exclusion is defined as the whole mixed process for some reasons such as unemployment and insecurity, resulting in the lack of substitution and weakening of the bonds, which can be determined by objective and subjective criteria. It is defined as the structure where social integration does not take 
place, which may deprive some groups of their basic needs, leading to the inability to benefit from social and political rights (Sapancali 2005: 53). Social exclusion is to move away from community participation due to the lack of basic skills and lifelong learning opportunities, where people are thrown out of society in a multi-layered, mobility period, with the prevalence of poverty and discrimination. People find it difficult to reach social activities with indicators such as work, income, education, information, health facility and living conditions (Eurostat, 2010). In a different definition, social exclusion is a common problem defined by others as being ignored, overlooked and neglected (Tunca, 2010). In general terms, social exclusion can be defined as the opposition to social integration by being deprived of the rights of political, economic, civil and social citizenship (Walker, 1997). The concept of social exclusion has different dimensions. One of these dimensions is to prevent the individual from moving away from society and to prevent socialization, together with the insufficiency of the person to enter into society (Sahin, 2009). As can be experienced in many different groups and environments in society, the person may be exposed to ostracism at every stage of his/her life. When children play, adolescents may face this situation in their relations with each other. The individual feels self-excluded, trivial and worthless. Even the person within the group does not respond. Although no physical reaction is experienced, the individual suffers. Ostracism can also be defined as the reaction of the individual or group by being unresponsive to another individual or group. Rejection, exclusion, and ridicule in the individual environment are ignored in social situations. Ostracism which is seen intensely during adolescence causes many problems for adolescents. The fact that the individual does not have social relations with different perspectives and does not understand social norms leads the adolescents to ostracism.

The adolescence period is one of the most important periods concerning peer relations. Adolescents who are ignored, overlooked and neglected by individuals and groups in society, feel lonely. They use various methods to cope with their loneliness. The people who use the technology in this regard, gravitate towards the Internet because it has a structure that can respond to the need for socialization. They try to compensate for the support they do not receive from their families and their environment with the virtual world. Since online communication is more confidential and less risky than face-to-face communication, it is the choice of adolescents with high social anxiety (Zorbaz, 2013). Because of the individual's interaction with many people and positive feedback about identity, Internet technologies respond to adolescents' need to search for the ideal identity. The different profiles they create in the virtual world can adversely affect the individual's useful identity development and direct the person to different ideas and relationships. The fact that an individual creates a false identity can cause psychological damage, directs the adolescent to the virtual world and harms the relationship with the real world (Ceyhan, 2010). The Internet, which is used functionally, provides positive development of the adolescents, and the Internet which is used without function affects the individual negatively (Zorbaz, 2013).

Especially, school-aged adolescents' excessive use negatively affects their academic and personal development and makes them dependent. Additionally, young people who become addicted also start to lose their bonds with their social environment. Adolescents who have low social skills tend to go to the Internet to meet their needs and prefer to spend time on the Internet by refusing to communicate with their family and relatives face-to-face. Adolescents who are addicted after some time, may start to be ignored and neglected by their social environment. So long as the process continues in such a way, their social exclusion may become inevitable. On the contrary, the individuals who are ignored and neglected by their 
surroundings also try to compensate for the deficiencies and deprivations they experience within their social environment by finding a remedy in the virtual world through the Internet. As a result, it is thought that as the individuals who are socially excluded may become addicted to the Internet, the individuals who are addicted may also be at the risk of social exclusion as well.

Based on the literature review, social exclusion and Internet addiction were generally encountered in adolescents. However, there is no study on the relationship between Internet addiction and social exclusion. Therefore, it is thought that the study will fill an important gap in the field.

In this study, the answers to the following questions were answered:

1. Is there a relationship between social exclusion and Internet addiction in female adolescents?

2. Is "being disregarded" a significant predictor of the Internet addiction of the female adolescent?

3. Is exclusion a significant predictor of the Internet addiction of the female adolescent?

\section{Method}

\subsection{Research Design}

The relational screening method was used in the study. To make a general judgment about the universe in the relational survey model, a study is carried out on the sample selected from the population (Karasar, 2007).

\subsection{Population and Sample/ Study Group/Participants}

The population of the study consisted of female adolescents attending high schools of the Ministry of National Education in Diyarbakir. The sample group of the study consisted of 244 female adolescents aged 12-18 years, who were studying in the high schools of the Ministry of National Education in Cinar district of Diyarbakir. The sample group was chosen based on the simple random sampling method. In the simple random sampling method, a list of high schools in Cinar district of Diyarbakir was made and drawn. Two schools were elected by the draw. The demographic characteristics of the participants are given in Table 1.

Table 1. Demographical Distribution of Participants

\begin{tabular}{cccc}
\hline & & Min-Max & Aver \pm ss \\
\hline Age (year) & & $14-18$ & $15.46 \pm 0.97$ \\
\cline { 3 - 4 } & 9 & $\mathbf{n}$ & $\%$ \\
\hline Class (Grade) & 10 & 111 & 45.7 \\
& 11 & 86 & 35.4 \\
\hline Brother/Sister & One & 46 & 18.9 \\
\hline & Two & 1 & 0.4 \\
& Three & 10 & 4.1 \\
& Four and more than & 18 & 7.4 \\
& four & 214 & 88.1 \\
\hline School & Vocational and & 145 & 59.7 \\
& Technical School & & \\
\hline
\end{tabular}




\begin{tabular}{|c|c|c|c|}
\hline & $\begin{array}{c}\text { Anatolian (Academic) } \\
\text { School }\end{array}$ & 98 & 40.3 \\
\hline \multirow[t]{3}{*}{ Success } & Low & 7 & 2.9 \\
\hline & Medium & 192 & 79.0 \\
\hline & High & 44 & 18.1 \\
\hline \multirow[t]{2}{*}{ Living } & With family & 241 & 99.2 \\
\hline & With relatives & 2 & 0.8 \\
\hline \multirow[t]{4}{*}{ Where } & Town center & 5 & 2.1 \\
\hline & District & 98 & 40.3 \\
\hline & Village & 137 & 56.4 \\
\hline & Other & 3 & 1.2 \\
\hline Income (TL) & & $0-6000$ & $1560.62 \pm 942.38$ \\
\hline \multirow[t]{4}{*}{ Mother's education } & Not literate & 128 & 52.7 \\
\hline & $\begin{array}{c}\text { Elementary education } \\
\text { graduate }\end{array}$ & 105 & 43.2 \\
\hline & High school graduate & 9 & 3.7 \\
\hline & Associate Degree & 1 & 0.4 \\
\hline \multirow[t]{5}{*}{ Father's education } & Not literate & 22 & 9.1 \\
\hline & $\begin{array}{c}\text { Elementary education } \\
\text { graduate }\end{array}$ & 164 & 67.5 \\
\hline & High school graduate & 53 & 21.8 \\
\hline & Associate Degree & 2 & 0.8 \\
\hline & Bachelor's Degree & 2 & 0.8 \\
\hline \multirow[t]{5}{*}{ Mother's job } & Worker & 3 & 1.2 \\
\hline & Self-employment & 6 & 2.5 \\
\hline & Housewife & 230 & 94.7 \\
\hline & Retired & 3 & 1.2 \\
\hline & Other & 1 & 0.4 \\
\hline \multirow[t]{7}{*}{ Father's job } & Civil Servant & 8 & 3.3 \\
\hline & Worker & 26 & 10.7 \\
\hline & Farmer & 64 & 26.3 \\
\hline & Self-employment & 78 & 32.1 \\
\hline & Doesn't work & 30 & 12.3 \\
\hline & Retired & 18 & 7.4 \\
\hline & Other & 19 & 7.8 \\
\hline
\end{tabular}

The ages of the participants ranged from 14 to 18 years with a mean age of $15.46 \pm 0.97 ; 45.7 \%$ $(n=111)$ in the 9 th grade, $35.4 \%(n=86)$ in the 10th grade and $18.9 \%(n=46)$ in the 11th grade students; while $0.4 \%(n=1)$ had siblings, $4.1 \%(n=10)$ had two, $7.4 \%(n=18)$ had 3 and $88.1 \%(n=$ 214) had four or more siblings; $59.7 \%(n=145)$ were in the vocational and technical high schools, 40.3\% ( $n=98)$ were the Anatolian high school students; $2.9 \%(n=7)$ had low school success, 79\% ( $n=192)$ had moderate level, 18.1\% ( $n=44)$ were successful; 99.2\% $(n=241)$ and $0.8 \%(n=2)$ were living with relatives; $2.1 \%(n=5)$ live in the city center, $40.3 \%(n=98)$ in the district, $56.4 \%(n=137)$ in the village and $1.2 \%(n=3)$ in other places. The monthly income of the families of the adolescents is between 0 and $6000 \mathrm{TL}$ and the average is $1560.62 \pm 942.38 \mathrm{TL}$. When the education levels of their mothers are examined, $52.7 \%(n=128)$ were not literate, $43.2 \%(n=105)$ were the primary school graduates, $3.7 \%(n=9)$ were high school graduates and $0.4 \%(n=1)$ held associate's degree. When the education levels of their fathers are examined; $9.1 \%(n=22)$ were not literate, $67.5 \%(n=164)$ were primary school graduates, $21.8 \%$ $(n=53)$ were high school graduates, $0.8 \%(n=2)$ held associate's degree and $0.8 \%(n=2)$ were undergraduate. $1.2 \%$ of the mothers $(n=3)$ were workers, $2.5 \%(n=6)$ were self-employed, $94.7 \%(n=230)$ were housewives, $1.2 \%(n=18)$ were retired, $0.4 \%(n=1)$ were found to have another profession. $3.3 \%$ of the fathers $(n=8)$ were civil servants, $10.7 \%(n=26)$ were workers, 
26.3\% ( $n=64)$ were farmers, $32.1 \%(n=78)$ were self-employed, $7.4 \%$ were employed. $7.4 \%(n=$ 18) were retired, $7.8 \%(n=19)$ had another occupation and $12.3 \%(n=30)$ did not work.

Table 2. Information Concerning the Participants

\begin{tabular}{|c|c|c|c|}
\hline & & $\mathrm{n}$ & $\%$ \\
\hline \multirow[t]{2}{*}{ Mobile Phone } & Yes & 107 & 44.0 \\
\hline & No & 136 & 56.0 \\
\hline \multirow[t]{11}{*}{ Provider } & Internet in the house & 48 & 19.8 \\
\hline & Smartphone & 110 & $45 \cdot 3$ \\
\hline & Friend's smartphone & 17 & 7.0 \\
\hline & Going to Internet Cafe & 12 & 4.9 \\
\hline & Other & 16 & 6.6 \\
\hline & Home Internet and Smartphone & 20 & 8.2 \\
\hline & Home Internet and Friend's Smartphone & 2 & 0.8 \\
\hline & His/Her Own smartphone and Friend's Smartphone & 14 & 5.8 \\
\hline & $\begin{array}{l}\text { Home, His/Her Own smartphone and Friend's } \\
\text { Smartphone }\end{array}$ & 2 & 0.8 \\
\hline & $\begin{array}{l}\text { His/Her Own smartphone and Friend's Smartphone } \\
\text { and other }\end{array}$ & 1 & 0.4 \\
\hline & $\begin{array}{c}\text { Everywhere } \\
\end{array}$ & 1 & 0.4 \\
\hline \multirow[t]{6}{*}{ Goal } & Social Media & 27 & 11.1 \\
\hline & Research & 159 & 65.4 \\
\hline & Other & 17 & 7.0 \\
\hline & Social media and research & 34 & 14.0 \\
\hline & Social media and other & 1 & 0.4 \\
\hline & Research and other & 5 & 2.1 \\
\hline \multirow[t]{6}{*}{ Frequency } & Never & 12 & 4.9 \\
\hline & Occasionally & 168 & 69.1 \\
\hline & Often & 26 & 10.7 \\
\hline & Most of the time & 31 & 12.8 \\
\hline & Always & 6 & 2.5 \\
\hline & & $\mathbf{N}$ & $\%$ \\
\hline \multirow[t]{2}{*}{ Friendship } & Yes & 37 & 15.2 \\
\hline & No & 206 & 84.8 \\
\hline \multirow[t]{5}{*}{ Prioritizing Career } & Never & 104 & 42.8 \\
\hline & Occasionally & 107 & 44.0 \\
\hline & Often & 7 & 2.9 \\
\hline & Most of the time & 18 & 7.4 \\
\hline & Always & 7 & 2.9 \\
\hline \multirow[t]{5}{*}{$\begin{array}{l}\text { Without the } \\
\text { Internet }\end{array}$} & Never & 116 & 47.7 \\
\hline & Occasionally & 71 & 29.2 \\
\hline & Often & 8 & 3.3 \\
\hline & Most of the time & 26 & 10.7 \\
\hline & Always & 22 & 9.1 \\
\hline \multirow[t]{5}{*}{ Spending time } & Never & 142 & 58.4 \\
\hline & Occasionally & 71 & 29.2 \\
\hline & Often & 6 & 2.5 \\
\hline & Most of the time & 19 & 7.8 \\
\hline & Always & 5 & 2.1 \\
\hline \multirow[t]{3}{*}{ Free time } & Studying, reading books, etc.. & 110 & $45 \cdot 3$ \\
\hline & Sports, dancing, etc. & 4 & 1.6 \\
\hline & Sleeping, music, TV, the Internet, etc. & 101 & 41.6 \\
\hline
\end{tabular}




\begin{tabular}{ccrr}
\hline & Spending time with family and friends & 28 & 11.5 \\
\hline Being noticed & With words & 44 & 18.1 \\
& Behavior, attitude, demeanor, etc. & 180 & 74.1 \\
& Others & 19 & 7.8 \\
\hline Communication & Family & 139 & 57.2 \\
& Friend, cousin & 48 & 19.8 \\
& Nobody & 56 & 23.0 \\
\hline
\end{tabular}

$44 \%(n=107)$ of the adolescents who make up the sample have a smartphone; $19.8 \%(n=48)$ have Internet access from home Internet, $45.3 \%(n=110)$ from smartphone, $7 \%(n=17)$ from friend's phone, $4.9 \%(n=12)$ through Internet café, 6.6\% $(n=16)$ through other means, $8.2 \%(n$ $=20)$ from home phone and smartphone, $0.8 \%(n=2)$ from home phone and friend phone, $5.8 \%(n=14)$ from their own and friend's phone, $0.8 \%(n=2)$ from home, from their own and friend's phone, $0.4 \%(n=1)$ from their own and friend's phone, and otherwise, $0.4 \%(n=1)$ from anywhere; $11.1 \%(n=27)$ of the Internet was the most frequently used social media, $65.4 \%$ $(n=154)$ of the research, $7 \%(n=17)$ from the others, $14 \%(n=34)$ from media and social research, $0.4 \%(n=1)$ from social media and others, and $2.1 \%(n=5)$ from research and others. It was determined that $15.2 \%$ of the participants $(n=37)$ established new friendships via Internet. $42.8 \%(n=104)$ answered "never" to the question if they look at the Internet as the first job before doing the necessary work. 44\% $(n=107)$ responded "rarely", $2.9 \%(n=7)$ responded "frequently". 7.4\% $(n=18)$ responded "most of the time", while $2.9 \%(n=7)$ responded "always". $47.7 \%(n=116)$ of the adolescents responded "never" to the question: Do you feel free and boring? "29.2\% ( $n=71)$ answered "rarely", 3.3\% $(n=8)$ answered "often", 10.7 $\%(n=26)$ answered" often" and 9.1\% $(n=22)$ answered "at any time". 58.4\% ( $n=142)$ answered "never" to the question: Do you neglect your day-to-day work on the Internet?. 29.2\% ( $n=71)$ answered "rarely", 2.5\% ( $n=6)$ answered "frequently", 7.8\% ( $n=19)$ answered "most of the time" and 2.1\% ( $n=5)$ answered "always". 45.3\% ( $n=110)$ answered "studying, reading books, etc." to the question: How do you evaluate your free time?, $1.6 \%(n=4)$ answered "sports, dancing, etc.", 41.6\% ( $n=101)$ answered "sleeping, music, TV, Internet, etc.", and $11.5 \%(n=28)$ answered "spending time with friends and family". $18.1 \%(n=44)$ answered the question: How can you tell if you care/ignore with words?, $74.1 \%(n=180)$ answered "behavior, attitude, demeanor, etc." and 7.8\% ( $n=19)$ answered "others". $57.2 \%(n=$ 139) answered" Family" to the question: 'Whom can you contact when you have a problem?' $19.8 \%(n=48)$ answered" friend and cousin", and $23 \%(n=56)$ did not answer.

\subsection{Data Collection Tools}

To determine the exclusion of adolescents in social relations as a data collection tool, the Social Exclusion Scale for Adolescents developed by Gilman, Carter-Sowell, Dewall, Adams, and Carboni (2013) and adapted to Turkish by Akin, Uysal, and Akin (2016) was used. Besides, Young Internet Addiction Short Form, which was developed by Young (1998) and adapted to Turkish by Kutlu, Savci, Demir and Aysan (2016), was developed by Young (1998) to test the Internet addiction of adolescents was used.

Social Exclusion (Ostacism) Scale for Adolescents. Social Exclusion Scale for Adolescents was developed by Gilman, Carter-Sowell, Dewall, Adams, and Carboni (2013) and adapted to Turkish by Akin, Uysal, and Akin (2016). The validity and reliability study of the scale were conducted with the participation of 306 high school students. Based on the confirmatory factor analysis, it was observed that the scale consisted of two sub-dimensions (neglect and exclusion) and 11 items. The factor loadings of the scale were .71 to .88 , and the item-total 
correlation coefficients ranged from .51 to .70 . The internal consistency reliability coefficient was .93 and .90. The total score of the scale was calculated as .89. The subscales in the scale are listed as disregard ( 5 items) and exclusion ( 6 items). The total score of the two sub-tests is called the Non-free score. The scale is applied to adolescents individually. The scale is never-1, rarely-2, often-3, usually-4 and always- 5 in the form of five-grade; the highest score is 55 and the lowest score is 11 . The higher the score obtained from the scale, the higher the perception of social exclusion.

Young Internet Addiction Short Form. The scale was developed by Young (1998) to test adolescents' Internet addiction. The short form was created by Pawlikowski, Altstotter-Gleich and Brand (2013). The scale was adapted to Turkish by Kutlu, Savci, Demir and Aysan (2016). The scale is composed of 12 items and has a five-degree degree (Never-1, Very frequent-5) and is one-dimensional. There are no items rated as reverse in the scale. Based on the confirmatory factor analysis, it was found that the one-dimensional model had good fit values in adolescents and factor loadings were sufficient for factor analysis. The internal consistency coefficient of the scale was calculated as 0.85 . High scores indicate that the level of Internet addiction is high on the scale.

\subsection{Data Collection}

The researcher got the approval of the application for the current study from the deanship of national education in Diyarbakir/Cinar. The decision was made to collect data between 01 April 2018 and 05 May 2018. The relevant school was visited on the specified dates; the data collection instruments were distributed among the students during the lessons as deemed appropriate and the students were asked to fill in the data collection instruments. As a result, a total of 244 data collection instruments were obtained.

\subsection{Data Analysis}

For statistical analysis, the NCSS (Number Cruncher Statistical System) 2007 (Kaysville, Utah, USA) program was used. Descriptive statistical methods (mean, standard deviation, median, first quarter, third quarter, frequency, percentage, minimum and maximum) were used to evaluate the study data. The normal distribution of quantitative data was tested with the Shapiro-Wilk test and graphical investigations. Independent groups t-test were used to compare the quantitative variables that did not show normal distribution. Kruskal-Wallis test and Dunn-Bonferroni test were used to compare more than two groups of quantitative variables that did not show normal distribution. Spearman correlation analysis was used to evaluate the relationships between quantitative variables. Statistical significance was accepted as $p<0.05$.

\section{Findings}

There was no statistically significant difference between the participants' social exclusion scores ( $p>0.05$; see Table 3 ). There was no statistically significant difference in social exclusion scores according to the success levels of the participants ( $p>0.05$, see Table 3 ). A statistically significant difference was found in terms of social exclusion scores of the participants ( $p$ : 0.005 , see Table 3 ). Based on the dual evaluations using Dunn-Bonferroni post-hoc tests, it was found that the social exclusion score of the participants living in the village was lower than that of the participants living in the district ( $p: 0.036$, see Table 3). There was no 
statistically significant difference in social exclusion scores ( $p>0.05$, see Table 3$)$. There was no statistically significant difference in social exclusion scores of participants based on Internet usage ( $p>0.05$, see Table 3 ). There was no statistically significant difference in social exclusion scores based on the frequency of Internet usage of the participants ( $p>0.05$; see Table 3 ). There was no statistically significant difference in social exclusion scores based on participants' leisure time ( $p>0.05$; see Table 3 ).

Table 3. Assessments by Social Exclusion

\begin{tabular}{|c|c|c|c|c|c|}
\hline & & $\mathbf{n}$ & $\begin{array}{l}\text { Social } \\
\text { Exclusion }\end{array}$ & $\begin{array}{l}\text { Test } \\
\text { value }\end{array}$ & p \\
\hline & & & 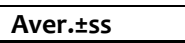 & & \\
\hline Class & 9 & 111 & $25.95 \pm 6.07$ & 2.963 & ${ }^{\mathrm{a}} 0.054$ \\
\hline (Grade) & 10 & 86 & $23.97 \pm 5.71$ & & \\
\hline & 11 & 46 & $25.41 \pm 4.81$ & & \\
\hline$¥$ Success & Low & 7 & $27(24,35)$ & 1.851 & $\mathrm{~b}_{0.396}$ \\
\hline & Medium & 192 & $25(21,29)$ & & \\
\hline & High & 44 & $25(20,31)$ & & \\
\hline ¥Where & Town center & 5 & $24(20,24)$ & 12.735 & ${ }^{\mathrm{b}} 0.005^{* *}$ \\
\hline & District & 98 & $26.5(23,30)$ & & \\
\hline & Village & 137 & $24(20,28)$ & & \\
\hline & Other & 3 & $18(18,22)$ & & \\
\hline Mobile & Yes & 107 & $25.93 \pm 6.02$ & 1.904 & ${ }^{c} 0.058$ \\
\hline Phone & No & 136 & $24.52 \pm 5.51$ & & \\
\hline ¥Provider & Internet in the house & 48 & $26(20,29.5)$ & 8.541 & ${ }^{\mathrm{b}} 0.129$ \\
\hline & Smartphone & 110 & $24.5(21,28)$ & & \\
\hline & Friend's smartphone & 17 & $22(18,27)$ & & \\
\hline & Going to Internet Cafe & 12 & $27(19.5,33.5)$ & & \\
\hline & Other & 16 & $26(21,30)$ & & \\
\hline & Multiple places & 40 & $26.5(24,30.5)$ & & \\
\hline †Gain & Social Media & 27 & $24(20,27)$ & 1.786 & bo.409 \\
\hline & Research & 159 & $25(20,29)$ & & \\
\hline & Other & 23 & $27(23,29)$ & & \\
\hline & Social media and research & 34 & $25.5(23,29)$ & & \\
\hline Frequency & Never & 12 & $23.5(18,28.5)$ & 2.813 & $\mathrm{~b}_{0.590}$ \\
\hline & Occasionally & 168 & $25(21,29)$ & & \\
\hline & Often & 26 & $24(22,29)$ & & \\
\hline & Most of the time & 31 & $26(24,29)$ & & \\
\hline & Always & 6 & $24.5(20,32)$ & & \\
\hline ¥Free time & Studying, reading books, etc. & 110 & $26(22,30)$ & 4.496 & ${ }^{b} 0.213$ \\
\hline & Sports, dance, etc. & 4 & $26(25.5,27.5)$ & & \\
\hline & Sleeping, music, TV, the Internet, etc. & 101 & $24(21,28)$ & & \\
\hline & Spending time with family and friends & 28 & $23.5(20.5,28)$ & & \\
\hline $\begin{array}{l}\text { One-way ana } \\
* * p<0.01 \\
\neq \text { The results }\end{array}$ & $\begin{array}{l}\text { sis of variance } \\
\text { ere presented as median (first quarter, th }\end{array}$ & quar & Indepenc & t group & t-test \\
\hline
\end{tabular}


Table 4. Evaluations According to Internet Addiction

\begin{tabular}{|c|c|c|c|c|c|}
\hline & & \multirow{2}{*}{$\mathbf{n}$} & Internet Addiction & \multirow{2}{*}{$\begin{array}{l}\text { Test } \\
\text { value }\end{array}$} & \multirow[b]{2}{*}{$\mathbf{p}$} \\
\hline & & & Median (Q1, Q3) & & \\
\hline \multirow[t]{3}{*}{ ‡Grade } & 9 & 111 & $19(15,29)$ & 0.129 & 0.938 \\
\hline & 10 & 86 & $19(16,26)$ & & \\
\hline & 11 & 46 & $20.5(14,29)$ & & \\
\hline \multirow[t]{3}{*}{ ‡Success } & Low & 7 & $23(19,34)$ & 2.881 & 0.237 \\
\hline & Medium & 192 & $19.5(15,28.5)$ & & \\
\hline & High & 44 & $17(15,25.5)$ & & \\
\hline \multirow[t]{4}{*}{ ¥Where } & Town center & 5 & $21(20,24)$ & 5.422 & 0.143 \\
\hline & District & 98 & $21(16,29)$ & & \\
\hline & Village & 137 & $18(15,27)$ & & \\
\hline & Other & 3 & $27(16,37)$ & & \\
\hline †Mobile & Yes & 107 & $21(16,29)$ & -2.404 & ${ }^{d} 0.016^{*}$ \\
\hline Phone & No & 136 & $18(14,27)$ & & \\
\hline \multirow[t]{6}{*}{ ‡Provider } & Internet in the house & 48 & $20.5(16,31.5)$ & 12.701 & ${ }^{\mathrm{b}} 0.026^{*}$ \\
\hline & Smartphone & 110 & $19(16,27)$ & & \\
\hline & Friend's Smartphone & 17 & $18(14,24)$ & & \\
\hline & Going to Internet Cafe & 12 & $14(12.5,19)$ & & \\
\hline & Other & 16 & $16(13,22.5)$ & & \\
\hline & Multiple places & 40 & $21(15 \cdot 5,33)$ & & \\
\hline \multirow[t]{4}{*}{ ‡Goal } & Social Media & 27 & $33(26,40)$ & 34.702 & ${ }^{b}<0.001 * *$ \\
\hline & Research & 159 & $17(14,23)$ & & \\
\hline & Other & 23 & $18(16,29)$ & & \\
\hline & Social media and research & 34 & $24.5(17,35)$ & & \\
\hline \multirow[t]{5}{*}{ †Frequency } & Never & 12 & $14.5(12,18.5)$ & 54.036 & ${ }^{b}<0.001^{* *}$ \\
\hline & Occasionally & 168 & $17(15,23)$ & & \\
\hline & Often & 26 & $28(23,37)$ & & \\
\hline & Most of the time & 31 & $29(21,36)$ & & \\
\hline & Always & 6 & $38(28,39)$ & & \\
\hline \multirow[t]{4}{*}{ †Free time } & $\begin{array}{l}\text { Studying, reading books, } \\
\text { etc. }\end{array}$ & 110 & $17.5(14,23)$ & 24.898 & ${ }^{\mathrm{b}}<0.001^{* *}$ \\
\hline & Sports, dance, etc. & 4 & $29.5(19,35)$ & & \\
\hline & $\begin{array}{l}\text { Sleeping, music, TV, the } \\
\text { Internet, etc. }\end{array}$ & 101 & $24(17,34)$ & & \\
\hline & $\begin{array}{l}\text { Spending time with family } \\
\text { and friends }\end{array}$ & 28 & $16.5(14.5,22)$ & & \\
\hline
\end{tabular}

\footnotetext{
${ }^{\mathrm{b}}$ Kruskal-Wallis test ${ }^{\mathrm{d}}$ Mann-Whitney $\mathrm{U}$ test

$* * p<0.01$
}

$\ddagger$ The results were presented as median (first quarter, third quarter).

There was no statistically significant difference in Internet dependence scores of the participants ( $p>0.05$ ). There was no statistically significant difference in Internet addiction scores according to the success levels of the participants $(p>0.05)$. There was no statistically significant difference in Internet addiction scores of the participants ( $p>0.05$; see Table 4 ).

There was a statistically significant difference in Internet addiction scores according to the way participants provided access to the Internet ( $p$ : 0.026, see Table 4). Based on the double evaluations carried out using Dunn-Bonferroni post-hoc tests, the scores of participants using the Internet at home were found to be higher than those of the participants attending the Internet café ( $p$ : 0.030; see Table 4). 
A statistically significant difference was found in Internet addiction scores of participants according to Internet usage $(p<0.001)$. Dunn-Bonferroni's post-hoc tests were used to evaluate the results of the study; The aim of using the scores of the participants with social media was found to be higher than that of the other participants ( $p<0.001, p: 0.011$, respectively; see Table 4).

It was found that the scores of the participants who were using the Internet for social media and doing research were higher than those of the participants whose aim was to make research ( $p$ : 0.001). There was a statistically significant difference between the Internet dependence scores of the participants based on the frequency of Internet usage $(p<0.001)$. Dunn-Bonferroni's post-hoc tests were used to evaluate the results of the study. The scores of the participants who did not use the Internet frequently were found to be lower than those of the participants who used it frequently and often ( $p: 0.001, p<0.001, p: 0.004$, respectively; see Table 4).

The scores of the participants, who rarely used the Internet were found to be lower than those of the participants who used it frequently, most of the time and all the time $(p<0.001, p$ $<0.001, p: 0.014$, respectively). There was a statistically significant difference in Internet addiction scores based on the participants' leisure time $(p<0.001)$. Dunn-Bonferroni's post-hoc tests were performed to evaluate the results of the study i.e. spending time with friends and family, to assess the scores of participants i.e. spending time with music, TV, Internet, etc., spending their free time and studying, reading books and so on. ( $p: 0.005, p<0.001$, respectively; see Table 4).

Table 5. The Relationship between Social Exclusion and Internet Addiction

\begin{tabular}{ll}
\hline & EODO Total - YIBT_KF \\
\hline$R$ & 0.021 \\
$P$ & $\mathbf{0 . 7 4 1}$ \\
\hline Spearman correlation coefficient &
\end{tabular}

Spearman correlation coefficient

There was no statistically significant relationship between exclusion scores and Internet addiction scores of the participants ( $p>0.05$, see Table 5 ).

\section{Discussion, Conclusion}

When the field related to Internet addiction is examined, the studies started in 1995 and gained momentum with the increase in Internet usage in recent years (Dogan, 2013). Nowadays, the Internet has become an indispensable part of life. Uncontrolled continuous use of the Internet has begun to lead to addiction. In our country, Internet addiction is generally seen among the children and young people with higher technology. Young (2004) in his study emphasized that problematic Internet use adversely affected the academic and social development of individuals.

According to the findings of the study, the minimum age was 14 years and the maximum age was 18 years. The average age is 15-46. The majority of them are the gth-grade students. There were significant differences between the number of siblings and the Internet addiction of adolescents. 214 out of the 244 students who participated in our study had 4 or more siblings. Dogan (2013) did not find any significant difference between adolescents' number of siblings and addiction level. 
The socioeconomic status of adolescents is low. There is a parallel relationship between the socioeconomic level and Internet usage, and as the family income level increases, there is an increase in Internet addiction levels. Greenfield (1999) emphasized that Internet usage has become cheaper and the ease of access has emerged as a major cause of Internet addiction (Dogan, 2013). Gunuc (2009) and Sahin (2011) found that there was a linear relationship between the socio-economic level of the families and the Internet use of adolescents and that the level of Internet addiction increased as the income level increased.

All participants (but two) live with their families. While the majority of these individuals who live with their families are living in the villages, the other part resides in the districts, centers, and other places. In the present study, it was found that there was a statistically significant difference in social exclusion scores of the participants. Based on the conducted dual evaluations, it was found that the social exclusion score of the participants living in the village was lower than that of the participants living in the district. This may be due to the limited capacity of adolescents to connect to the Internet in the village.

Occupations of the individuals' father in the study group show close distributions. In a few studies, it was stated that the working status of the parents did not have an impact on adolescents' levels of Internet addiction. Dogan (2013) has found that the educational level of mother and father does not affect the level of Internet addiction of the adolescent in his study; however, mother's working status affects the adolescent's level of Internet addiction. The majority of mothers were illiterate and primary school graduates. It was determined that 230 mothers were housewives. In some studies, there was a significant difference between Internet addiction and parental education level. Inan (2010), Batigun \& Kilic (2011) found that Internet addiction increased as the mother's education level increased. Similarly, Gunuc (2009) and Dogan (2013) reported that the level of education was not related to addiction. In another study, as the level of family education decreases, the level of Internet addiction increases and as the education level of the person increases, the tendency towards Internet addiction decreases (Dogan, 2013).

In a different study, it has been stated that satisfaction in family relations does not have a significant effect on Internet addiction (Derin \& Bilge, 2016).

While 139 out of 244 people talk to their families when they have a problem, 48 of them get in touch with their cousin and 56 of them do not contact anyone. In the literature, it is stated that as the satisfaction in the relationship with the others increases, the risk of being addicted to the Internet decreases (Esen \& Siyez, 2011). Generally, adolescents prefer to share their problems with their peers instead of sharing them with their families, teachers or other adults. They express their feelings and thoughts with their peers more easily. Therefore, it can be said that the adolescents who interact with their friends and the individuals they care about, meet their psychosocial needs and are less attracted to the Internet.

According to the classes of adolescents participating in the study, there was no statistical difference between Internet addiction and adolescents. In a different study, it was observed that the level of Internet addiction decreased as the students' grade levels increased (Gunuc, 2009; Dogan, 2013). In Derin and Bilge's (2016) studies, it is stated that class level has no significant effect on Internet addiction. 
There was no change in the risk of Internet addiction based on their success levels. However, in the conducted studies, it was found that the levels of Internet addiction increased as individuals' academic achievement levels decreased (Derin, 2013). Similarly, in a similar study, it was found that the likelihood of Internet addiction increased as the academic success level decreased (Derin \& Bilge, 2016). In the research, it was found that moderate success was dominant. In our study, no statistically significant difference was found in social exclusion scores of participants according to their success levels and place of residence. The limitations of the study are that the study was performed in Diyarbakir Cinar district and most of the participants lived in the village.

Based on the smartphone availability, there was a significant relationship in Internet addiction risk ratios. Participants who had smartphones had higher Internet addiction risk than those without smartphones. It can be thought that smartphones do not remain connected to a fixed place, they can be moved everywhere and they can increase their risk of Internet addiction because they have the property of being at the moment.

In the study, there were statistically significant differences in Internet addiction level based on the way of providing Internet access. The dependency risks of individuals using the Internet at home were found to be higher than those going to the Internet café. In a study, it was found that adolescents were usually connected to the Internet at home. Besides, adolescents who are addicted to the Internet have a higher rate of dependency in the individuals who are connected to the Internet at home because they are easily connected to the Internet at any time, there is no environmental pressure, and it is free and unlimited (Dogan 2013; Dogan et. al., 2008). In another study, it was found that individuals with their computers had higher risks of dependence than those without their computers (Dogan, 2013).

It was found that there was a statistically significant difference in Internet addiction scores of the adolescents who participated in the study according to their most frequent purposes of use. Based on the evaluations, it was found that the addiction levels of the participants using social media were higher than those of the other participants. In a study, it was found that adolescents used the Internet to have the most fun and spend time. The second place is to communicate (Gunlu, 2016). Ceyhan (2007) in his study on the Internet to spend time, entertain and relax individuals who use the Internet has found problematic Internet use. Dogan (2013) in his study to use the Internet among adolescents, found that while the aim of adolescents' using the Internet was to enter more social networks, the dependence level of the users who used the Internet to chat was higher in the literature.

In his study, Young (1997) emphasized that the reasons for using the internet make a significant difference between the dependent and non-dependent individuals. While the Internet was used by the addicted individuals to chat, socialize with and meet new people, non-dependent individuals concluded that they use the Internet to do more research. According to the responses of the participants in the study, it was found that the majority of the participants used the internet to conduct research. This may be because the majority of the participants live in the village and there is a limitation in the possibilities of Internet access. There was a statistically significant difference in internet addiction scores of the participants according to their frequency of internet usage. As a result of the study, it was found that the levels of the participants who never used the Internet were lower than those who used the Internet frequently, often and always. Due to the increase in the time spent on the Internet, the possibility of Internet addiction increases (Derin \& Bilge, 2016). 
It was found that there was a statistically significant difference in Internet addiction scores of adolescents participating in the study based on their leisure time. As a result of the evaluation, leisure time to sleep, listen to music, watch TV, use the Internet, etc. to spend time with friends and family to evaluate the score of the participants, study, read books and so on, was found to be higher than that of the participants. In their study, Ozcan and Buzlu (2005) found that adolescents prefer the Internet to have fun in their free time.

According to the findings, there was no statistically significant relationship between Internet addiction and social exclusion. There are limitations to the research. One of the limitations of the study is that the research was conducted in a district and carried out only on female students. The findings of the present study can be supported in areas with good central and socioeconomic status.

\section{References}

Akin, A., Uysal, R. \& Akin, U. (2016). Ergenler Icin Ostrasizm (Sosyal Dislanma) Olceginin Turkce'ye Uyarlanmasi, Kastamonu Egitim Dergisi, 24(2), 895-904.

Batigun, A.D. \& Kilic, N. (2011). Internet Bagimliligi Ile Kisilik Ozellikleri, Sosyal Destek, Psikolojik Belirtiler ve Bazi Sosyo-Demografik Degiskenler Arasindaki Iliskiler, Turk Psikoloji Dergisi, 26 (67), 1-10.

Bolukbas, K. (2003). Internet Cafeler ve Internet Bagimliligi Uzerine Sosyolojik Bir Arastirma: Diyarbakir Ornegi. Yayimlanmamis Yuksek Lisans Tezi, Dicle Universitesi, Sosyal Bilimler Enstitusu.

Canogullari, O. (2014). Internet bagimlilik duzeyleri farkli ergenlerin cinsiyetlerine gore psikolojik ihtiyaclari, sosyal kaygilari ve anne baba tutum algilarinin incelenmesi. Yayinlanmamis Yuksek Lisans Tezi. Cukurova Universitesi Sosyal Bilimler Enstitusu, Adana.

Ceyhan, E. (2010). Problemli Internet Kullanim Duzeyi Uzerinde Kimlik Statusunun, Internet Kullanim Amacinin ve Cinsiyetin Yordayiciligi, Anadolu Universitesi Egitim Fakultesi, Egitim Bilimleri Bolumu, Ankara.

Ceyhan, E., Ceyhan A. A. \& Gurcan, A. (2007). Problemli internet kullanimi olceginin gecerlik ve guvenilirlik calismalari, Kuram ve Uygulamada Egitim Bilimleri Dergisi, (7), 387-416.

Derin, S. \& Bilge, F. (2016). Ergenlerde internet Bagimliligi ve Oznel lyi olus Duzeyi, Turkiye Psikolojik Danisma ve Rehberlik Dergisi, 46, 1302-1370.

Derin, S. (2013). Lise Ogrencilerinde Internet Bagimliligi ve Oznel lyi Olus. Master's thesis, Hacettepe Universitesi, Egitim Bilimleri Anabilim Dali, Ankara

Dogan, A. (2013). Internet Bagimliligi Yayginligi. Master's thesis, Aile Egitimi ve Danismanligi Anabilim Dali, Izmir.

Dogan, H., Isiklar, A. \& Eroglu, S. S. (2008). Ergenlerin problemli internet kullaniminin bazi degiskenler acisindan incelenmesi, Ataturk Universitesi Kazim Karabekir Egitim Fakultesi Dergisi, 8, 106-124.

Esen, E. \& Siyez, D. (2011). Ergenlerde internet bagimliligini yordayan psiko-sosyal degiskenlerin incelenmesi, Turk PDR Dergisi, 4(36), 127-138.

Eurostat (2010). Eurostat Combating Poverty and Social Exclusion, 2010 Edition A Statical Portatit of the European Union, 2010. http://epp.eurostat.ec.europa.eu/cache/ITY_OFFPUB/KS- EP-09-001/EN/KS-EP-09-001EN.PDF (01.02.2010).

Gilman, R., Carter-Sowell A., DeWall, N., Adams, R., \& Carboni I. (2013). Validation of the Ostracism Experiences Scale for adolescents, Psychological Assessment, 25(2), 319-330. 
Greenfield, D.N. (1999). Psychological Characteristics of Compulsive Internet Use: A Preliminary Analysis, Cyberpsychology and Behaviour, 2, 403- 12.

Gunlu, A. (2016). Ergenlerde Internet ve Problemli Internet Kullanim Davranislarinin Inclenmesi. Master's thesis, Anadolu Universitesi, Egitim Bilimleri Enstitusu, Eskisehir.

Gunuc, S. (2009). Internet Bagimlilik Olceginin Gelistirilmesi ve Bazi Demografik Degiskenler Ile Internet Bagimliligi Arasindaki Iliskilerin Incelenmesi. Master's thesis, Yuzuncu Yil Universitesi, Sosyal Bilimler Enstitusu, Van.

Gwinnell, E. ve Adamec, C. (2006). The Encyclopedia of Addiction and Addictive Behaviours. Newyork-USA: Facts On File, Inc.

Inan, A. (2010). Ilkogretim II. Kademe ve Ortaogretim Ogrencilerinde Internet Bagimliligi. Master's thesis, Ataturk Universitesi, Sosyal Bilimler Enstitusu, Erzurum.

Karasar, N. (2007). Bilimsel Arastirma Yontemi. Ankara: Nobel Yayin Dagitim.

Kayri, M. \& Gunuc, S. (2009). Internet Bagimlilik Olceginin Turkce'ye Uyarlanmasi: Gecerlilik ve Guvenirlik Calismasi, Ankara Universitesi Egitim Bilimleri Fakultesi Dergisi, 42 (1), 157175.

Kutlu, M., Savci, M., Demir, Y. \& Aysan, F. (2016). Young Internet Bagimliligi Kisa Formunun Turkce Uyarlamasi: Universite ogrencileri ve ergenlerde gecerlilik ve guvenirlik calismasi. Anadolu Psikiyatri Dernegi, 17, 69-76

Minaz, A. \& Cetinkay, O. (2017). Universite Ogrencilerinin Akilli Telefon Bagimlilik Duzeylerinin ve Kullanim Amaclarinin Farkli Degiskenler Acisindan Incelenmesi. Mehmet Akif Ersoy Universitesi, Sosyal Bilimler Enstitusu Dergisi, 9 (21).

Ozcan, N. K. \& Buzlu, S. (2005). Problemli Internet Kullaniminin Belirlemede Yardimci Bir Arac: Internette Bilissel Durum Olcegi'nin Universite Ogrencilerinde Gecerlik ve Guvenilirligi. Bagimlilik Dergisi. 6 (1), 19-26.

Pawlikowski M, Altstotter-Gleich C. \& Brand M. (2013). Validation and psychometric properties of a short version of Young's Internet Addiction Test. Comput Human Behav, 29(3), 12121223.

Sahin, M. (2011). Ilkogretim Okulu Ogrencilerindeki Internet Bagimliligi. Unpublished master's thesis, Yeditepe Universitesi, Sosyal Bilimler Enstitusu, Istanbul.

Sahin, T. (2009). Sosyal Dislanma ve Yoksulluk Iliskisi, Sosyal Yardımlasma ve Dayanisma Genel Mudurlugu. Sosyal Yardim Uzmanlik tezi, Ankara.

Sapancali, F. (2005). Avrupa Birligi'nde Sosyal Dislanma Sorunu ve Mucadele Yontemleri, Calisma ve Toplum, 6, 51-106.

TUIK (2017). Hanehalki Bilisim Teknolojileri Kullanim Arastırmasi, 2017, erisim: 18 Agustos 2017, http://afyonluoglu.org/PublicWebFiles/stats/hbtk/2017-HBTK.pdf.

Tunca, R. (2010). Sosyal Dislanma Sorunu ve Mucadele Yontemleri (Canakkale Fevzi Pasa Mahallesi (Ornegi), Master's thesis, Canakkale On Sekiz Mart Universitesi Sosyal Bilimler Enstitusu, Canakkale.

Unal, M. H. (2015). Ankara Yildirim Beyazit Universitesi Tip Fakultesi Ogrencilerinin Akilli Telefon Bagimlilik Duzeylerinin Belirlenmesi. Doctorate dissertation, Saglik Bakanligi Yildirim Beyazit Universitesi Tip Fakultesi Aile Hekimligi Anabilim Dali, Ankara.

Walker, A. \& Walker, C. (1997). Britain Divided: The Growth of Social Exclusion in the 1980 s and 1990s, Child Poverty Action Group, London.

Yellowlees, P. M. ve Marks, S. (2007). Problematic Internet Use Or Internet Addiction. Computers In Human Behavior. 23: 1447- 1453.

Young KS. (1998). Caught in the Net: How to Recognize the Signs of Internet Addiction and a Winning Strategy for Recovery. New York: John Wiley \& Sons. 
Young, K. (1997). What makes the internet addictive: potential explanations for pathological Internet use. 100. Annual Conference of The American Psychological Association, Chicago (15 August 1997).

Young, K. (2004). Internet Addiction: A New Clinical Phenomenon and Its Consequences. The American Behavioral Scientist, 48 (1), $402-415$.

Zorbaz, O. (2013). Lise Ogrencilerinin Problemli Internet Kullaniminin Sosyal Kaygi ve Akran Iliskiler Acisindan Incelenmesi, Hacettepe Universitesi Sosyal Bilimler Enstitusu, Egitim Bilimleri Anabilim Dali, Psikolojik Danisma ve RehberlikBilim Dali, Yuksek Lisans Tezi, Ankara.

\section{Biographical notes:}

Asst. Prof. Dr. Oğuz Emre completed his bachelor's degree on Department of Classroom Education at the Inönü University 2003, master degree on Department of Special Education at the J.W. Goethe University 2007 and PhD degree on Department of Education in the institute of 'Elemeantary and Primary education at the J.W. Goethe University 2016. Starting from 2017, he serves as an assistant professor at Inonu University, Faculty of Health Sciences Department of Child Development. He has studies in child development, special education, preschool education, refugee children, trauma in children and child mental health.

Aynur Bağır was born in 1993 in Diyarbakır, where she finished elementary school and grammar school "Uros Predic". In 2016 she completed her bachelor studies at the Health Faculty, Ahi Evran University. In 2017, he started to study for master's degree at Inönü University and he is still continuing his education. Since 2016, she has been working as a Child Development and Education Teacher in Çınar, Diyarbakır/Turkey.

Prof. Dr. Hatice Birgül Cumurcu was born in 17.03.1973 in Bakırköy-İstanbul. She obtained a $\mathrm{PhD}$ degree in medicine from Medicine Faculty, Ankara University. She became a associate professor of Psychiatry in 2010. Since 2015, she has been working as a professor in the faculty of medicine at the Inönü University. Her field of research is addiction, substance addiction.

Assoc. Prof. Dr. Ayşegül Ulutas graduated from Inonu University Faculty of Education, Department of Preschool Education 2009. In 2011, she completed graduate education at the Inonu University Institute of Educational Sciences Department of Preschool Education, and in 2015, she received Ph.D. at Gazi University Department Institute of Educational Sciences, Department of Child Development and Education. Between 2009-2013, she worked as a research assistant at Adiyaman University Faculty of Education. Between 2013-2015, she served as an instructor at Inonu University. Starting from 2015, she serves as an assistant professor at Inonu University, Faculty of Health Sciences Department of Child Development. She has studies in family training, child development, preschool education, mother-child training, play in child development and children's literature. 